\title{
MONITORING ANTIBODI HPR PASCA VAKSINASI RABIES DI DKI JAKARTA TAHUN 2013-2015
}

\author{
Monitoring Atr Antibodi After Rabies Vaccination \\ at DKI Jakarta in 2013-2015
}

\author{
Inanusantri \\ Suku Dinas Ketahanan Pangan Kelautan dan Pertanian Kota Adminisrtrasi Jakarta Utara \\ Jl. Laksda Yos Sudarso No 27-29 Jakarta Utara \\ Email : inanusantri@yahoo.co.id
}

\begin{abstract}
Abstrak
Penyakit Rabies atau lebih dikenal sebagai penyakit anjing gila adalah penyakit viral zoonosis yang berbahaya, jika gejala klinis telah muncul maka akan menimbulkan kematian baik pada hewan maupun manusia, termasuk zoonosis langsung karena hanya memerlukan satu hewan vetebrata untuk mempertahankan siklus hidupnya dan agen penyakit tidak mengalami perubahan selama penularan. Surveilans penyakit rabies dilakukan Balai Kesehatan Hewan dan Ikan DKI Jakarta untuk mengevaluasi program vaksinasi rabies melalui pengukuran titer antibodi dan memberikan rekomendasi bagi pimpinan untuk mengambil kebijakan dalam menyusun program pengendalian dan pemberantasan rabies di lima wilayah kota DKI Jakarta dan Kabupaten Kepulauan Seribu. Jenis sampel yang diambil berupa sampel darah anjing, kucing dan kera di lima wilayah DKI Jakarta dan Kabupaten Kepulauan Seribu selama tahun 2013 s.d 2015. Jumlah sampel yang diambil sebanyak 2.405 sampel darah. Jenis pengujian yang digunakan adalah uji Elisa (Enzyme Linked Immunosorbent Assays). Kekebalan kelompok terhadap penyakit rabies di DKI Jakarta terus meningkat tahun 2013 tingkat protektivitas adalah 31,3\% dari 838 sampel, tahun 2014 tingkat protektivitas meningkat menjadi 36\% dari 878 sampel dan tahun 2015 dari 689 sampel terjadi peningkatan yang sangat tajam menjadi $64,0 \%$ sedikit dibawah standart yang diharapkan yaitu 70\%. Data ini memberikan gambaran titer antibodi rabies tahun 2013 sampai dengan 2015 di DKI Jakarta masih rendah. Hal ini mencerminkan HPR (Hewan Penular Rabies) yang berada di DKI Jakarta masih perlu mendapat perhatian. Selain itu juga perlu mendapat pengawasan lalu lintas ternak ke wilayah DKI Jakarta. Oleh karena itu diperlukan peran aktif dari instansi terkait untuk melakukan sosialisasi. Metode dalam kajian ini mengacu pada Enzyme Linked Immunosorbent Assay (Elisa) menggunakan Kit Elisa Rabies Pusat Veteriner Farma.
\end{abstract}

Kata kunci : rabies, zoonosis and elisa (enzyme linked immunosorbent assays).

\begin{abstract}
Rabies or more commonly known as hydrophobia is a dangerous viral zoonotic desease, if clinical symptoms have appeared, it will cause the death of both animals and humans, including direct zoonosis because it only requires one animal vetebrata for completion its life cycle and disease agent has not changed during transmission. Surveillance in rabies was caried in DKI Jakarta Animal and Fish Health Center to evaluate the rabies vaccination program through the measurement of antibody titers, and provide recomendations to the governance to take policies in composing rabies control and eradication program in five region of Jakarta city and the Thousand Islands District. The kind of sample that used were dog, cat and monkey blood in five region of Jakarta city and the Thousand Islands district from 2013 until 2015. The number of samples taken was 2.405 blood samples. Type of testing that used was the Elisa test (Enzyme Linked Immunosorbent Assays). Group immunity against rabies in DKI Jakarta is 2013 level protectivity 31,1\% from 838 samples, 2014 increase level protectivity 36\% from 878 samples and 2015 from 689 samples increase level protectivity in far 64\% low below the expected standard (70\%). This data gives an overview that rabies antibody titer in 2013-2015 in DKI Jakarta still low. This reflects that the HPR (Animal transmitting rabies) located in DKI Jakarta still need attention. It also needs to have traffic control of livestock to areas of DKI Jakarta. It is therefore necessary active participation of related institutions to socialize it. The method in this study refers to the work instructions Elisa Kit Rabies Veterinary Center Farma.
\end{abstract}

Keywords : rabies, zoonosis, and elisa (enzyme linked immunosorbent assays). 
I. PENDAHULUAN

Rabies adalah penyakit hewan menular strategis yang ditetapkan pemerintah Indonesia untuk dapat dibebaskan pada tahun 2020 bersama dengan target bebas rabies se-Asia Tenggara. Untuk mencapai target tersebut maka status wilayah yang bebas rabies harus dipertahankan, yang endemis diturunkan tingkat kejadian penyakitnya sampai pada tingkat nol kasus dan dipertahankan terus menerus minimal selama dua tahun tidak ada kasus, maka target Indonesia bebas rabies akan tercapai. Jakarta sebagai salah satu wilayah yang bebas rabies harus juga mempertahankan kondisi bebas tersebut dengan surveilan yang terstruktur terus menerus untuk menjamin rabies tidak akan muncul lagi.

DKI Jakarta telah melaksanakan surveilans rabies secara terus menerus untuk membuktikan bahwa di wilayah DKI Jakarta bebas rabies. Diperlukan bukti tidak terdapatnya antigen virus rabies untuk mengantisipasi dan mencegah masuknya penyakit rabies yang ditularkan melalui hewan penular rabies. Penyakit rabies atau yang sering dikenal dengan nama penyakit Anjing Gila adalah suatu penyakit hewan menular yang disebabkan oleh virus, bersifat akut yang menyerang susunan syaraf pusat pada hewan berdarah panas atau manusia. Penyakit ini merupakan penyakit viral zoonosis yang berbahaya. Jika gejala klinis telah muncul, maka akan menimbulkan kematian baik pada hewan maupun manusia. Anjing adalah vektor utama pada infeksi ke manusia tetapi epidemiologi rabies berbeda tergantung dari geografis negara masing-masing.

Berdasarkan SK Mentan No 556/KPTS/PD 640/10/2004 tanggal 6 Oktober 2004 DKI Jakarta dinyatakan sebagai daerah bebas rabies. Sebagaimana ketentuan dunia melalui OIE untuk bisa memenuhi ketentuan bahwa suatu negara atau wilayah bebas penyakit rabies maka negara atau wilayah tersebut apabila diketemukan harus dilaporkan (notifiable disease), karena merupakan penyakit prioritas dan wilayah tersebut mempunyai sistem surveilans rabies yang terstruktur, tidak diketemukan kasus rabies pada hewan dan pada manusia selama dua tahun berturut-turut dan juga selama 6 bulan terakhir tidak ditemukan kasus rabies pada mamalia di wilayah karantina. Dalam upaya memenuhi ketentuan tersebut DKI Jakarta sebagai wilayah yang telah dinyatakan bebas rabies maka DKI Jakarta telah melaksanakan surveilans lebih terstruktur sejak tahun 2003 dengan melaksanakan sesuai dengan kaidahkaidah epidemiologis didalam penentuan sampel, distribusi sampel yang proposional, pengambilan sampel dan analisis hasil.

Adapun tujuan dari kajian ini adalah untuk mengetahui titer antibodi rabies pada HPR (Hewan Penular Rabies) di DKI Jakarta sejak tahun 2013 sampai dengan 2015, sehingga dapat digunakan sebagai bahan masukkan bagi pimpinan untuk pencegahan dan pengendalian rabies di Propinsi DKI Jakarta. Rabies merupakan salah satu penyakit strategis yang perlu ditangani. Metode yang digunakan pada kajian ini Enzyme Linkked Sorben Assays (ELISA) mengacu pada kit Elisa Rabies Pusat Veteriner Farma.

\section{TINJAUAN PUSTAKA}

Direktorat Kesehatan Hewan, Direktorat Jenderal Pertanian dan Kesehatan Hewan Kementrian Pertanian Republik Indonesia (2014) menyatakan "Surveilans diperlukan untuk menunjukkan keadaan bebas penyakit dan deteksi dini untuk penyakit eksotis serta penyakit yang baru muncul atau yang muncul kembali".

Menurut Madigan M.T., et al (2009) rabies adalah penyakit infeksi tingkat akut pada susunan syaraf pusat yang disebabkan oleh virus rabies. Penyakit ini bersifat zoonotik, yaitu dapat ditularkan dari hewan ke manusia. Virus rabies ditularkan ke manusia melalui gigitan hewan misalnya oleh anjing, kucing, kera, rakun dan kelalawar. Meskipun semua mamalia peka terhadap rabies, hanya spesies dari jenis canid, viverrid (skunks and raccoons) and chiropteran (kelalawar) adalah vektor yang paling efisien untuk rabies (Mrak R.E and Young L, 1994).

Jackson, A.C. (2000) menyatakan anjing adalah vektor utama pada infeksi ke manusia. Rabies disebut juga penyakit anjing gila (Smith J.S., 1990). Sedangkan Steele J.H. and Fernandes P.J. (1991) berpendapat rabies penyakit encepalitis bersifat akut, progresif dan belum ada obatnya yang disebabkan oleh virus rabies yang sudah sangat lama dikenal manusia sebagai penyakit yang bisa menular dari hewan ke manusia.

Berdasarkan laporan OIE dinyatakan bahwa penyakit Rabies di negara berkembang merupakan urutan nomor 2 (dua) yang paling ditakuti wisatawan mancanegara setelah penyakit malaria. Pemerintah Indonesia melalui Direktorat Jenderal Peternakan dan Kesehatan Hewan, Kementrian Pertanian telah menetapkan rabies sebagai penyakit hewan menular prioritas utama yang harus ditangani. 
Menurut Wirblich C. Tan G.S (2008) rabies disebabkan oleh virus rabies yang masuk ke keluarga Rhabdoviridae dan genus Lysavirus. Karakteristik utama virus keluarga Rhabdoviridae adalah hanya memiliki satu utas negatif RNA yang tidak bersegmen. Virus ini hidup pada beberapa jenis hewan yang berperan sebagai perantara penularan. Hewan perantara menginfeksi inang yang bisa berupa hewan lain atau manusia melalui gigitan. Infeksi juga dapat terjadi melalui jilatan hewan perantara pada kulit yang terluka. Setelah infeksi, virus akan masuk melalui saraf-saraf menuju ke sumsum tulang belakang, otak dan bereplikasi di sana. Selanjutnya virus akan berpindah lagi melalui saraf ke jaringan non saraf, misalnya kelenjar liur dan masuk ke dalam air liur. Virus tersebar luas dalam tubuh hewan yang terinfeksi terutama susunan syaraf pusat, air liur, urine, getah bening, susu dan darah (Rabies Bulletin-Europa, 2011).

Steele J.H and Fernandez P.J (1991) mengungkapkan hewan yang terinfeksi bisa mengalami rabies buas/ganas ataupun rabies jinak/ tenang. Pada rabies buas/ganas, hewan yang terinfeksi tampak galak, agresif, menggigit dan menelan segala macam barang, air liur terus menetes, meraung-raung gelisah kemudian menjadi lumpuh dan mati. Pada rabies jinak/tenang, hewan yang terinfeksi mengalami kelumpuhan lokal atau kelumpuhan total, suka bersembunyi di tempat gelap, mengalami kejang dan sulit bernapas, serta menunjukkan kegalakan. Sumber penularan rabies yang utama ke manusia adalah anjing. Kucing dan kera dapat tertular rabies dari anjing namun mata rantai siklus pada hewan

Jika seseorang digigit hewan, maka hewan yang menggigit harus diawasi (US Department of Health and Human Services, 2011). Menurut Nadin, et al (2011) satusatunya uji yang menghasilkan keakuratan $100 \%$ terhadap adanya virus rabies adalah dengan uji antibodi fluoresensi langsung (direct fluorescent antibody test/ dFAT) pada jaringan otak hewan yang terinfeksi. Uji ini telah digunakan lebih dari 40 tahun dan dijadikan standar dalam diagnosis rabies. Prinsipnya adalah ikatan antara antigen rabies dan antibodi spesifik yang telah dilabel dengan senyawa fluoresens yang akan berpendar sehingga memudahkan deteksi. Namun, kelemahannya adalah subjek uji harus disuntik mati terlebih dahulu (eutanasia) sehingga tidak dapat digunakan terhadap manusia. Akan tetapi, uji serupa tetap dapat dilakukan menggunakan serum, cairan sumsum tulang belakang, atau air liur penderita walaupun tidak memberikan keakuratan 100\%. Selain itu,
Rabies Bulletin-Europa (2011) menjelaskan diagnosis dapat juga dilakukan dengan biopsi kulit leher atau sel epitel kornea mata walaupun hasilnya tidak terlalu tepat sehingga nantinya akan dilakukan kembali diagnosis post mortem setelah hewan atau manusia yang terinfeksi meninggal.

Menurut Wirblich C. Tan G.S (2008), jika gejala penyakit telah nampak, maka rabies bersifat fatal baik pada hewan maupun manusia. Sedangkan dalam Chalton, et al (1997) dituliskan rabies dapat diobati, namun harus dilakukan sedini mungkin sebelum menginfeksi otak dan menimbulkan gejala. Bila gejala mulai terlihat, tidak ada pengobatan untuk menyembuhkan penyakit ini Kematian biasanya terjadi beberapa hari setelah terjadinya gejala pertama.

Penelitian yang dilakukan Madigan M.T., et al (2009) menyarankan bahwa bila terinfeksi rabies, segera cari pertolongan medis. Jika terjadi kasus gigitan oleh hewan yang diduga terinfeksi rabies atau berpotensi rabies (anjing, sigung, rakun, rubah dan kelalawar) segera cuci luka dengan sabun atau pelarut lain di bawah mengalir selama 10-15 menit lalu beri antiseptik alkohol $70 \%$ atau betadin".

Lebih lanjut, Steele J.H. and Fernandez P.J (1991) mengatakan bahwa orang-orang yang belum diimunisasi selama 10 tahun terakhir akan diberikan suntikan tetanus, sedangkan US Department of Health and Human Services (2014) menyatakan orangorang yang belum pernah mendapat vaksin rabies akan diberikan suntikan globulin imun rabies yang dikombinasikan dengan vaksin. Kadang-kadang terjadi rasa sakit, kemerahan, bengkak, atau gatal pada tempat penyuntikan vaksin.

Menurut Chaltron, et al (1997) hampir semua infeksi rabies pada hewan maupun manusia terjadi akibat gigitan anjing gila. Telah diteliti bahwa ada kemungkinan virus bereplikasi di serat otot sebelum menuju syaraf. Wirblich C Tan G.S. (2008) menambahkan virus menyebar dengan cepat sampai seluruh otak dan tulang belakang terinfeksi. Virus menyebar ke otak melalui syaraf tepi menuju syaraf pusat dengan kecepatan 50-100 mm perhari.

\section{METODE PENELITIAN}

Ruang menghitung besaran sampel yang akan digunakan untuk memprediksi tingkat kekebalan kawanan dari HPR (Hewan Penular 
Rabies) di wilayah DKI digunakan rumus sebagai berikut :

$$
N=9 P Q / L^{2}
$$

$\mathrm{n}=$ Besaran sampel yang dibutuhkan

$\mathrm{P}=$ Prediksi tingkat kekebalan kelompok yang mungkin

$$
\begin{aligned}
& Q=1-P \\
& L=\text { Tingkat kesalahan yang ditoleransi }(5 \%)
\end{aligned}
$$

Data untuk penulisan kajian ini diperoleh dari kegiatan survailans penyakit Rabies. Pelaksanaan pengambilan sampel dilakukan pada tahun 2013 - 2015. Sampel darah diambil dari HPR (Hewan Penular Rabies) yang dipelihara di lima wilayah kotamadya DKI Jakarta dan kabupaten kepulauan seribu. Sampel darah kemudian dibawa secara aseptis dan dingin ke Balai Kesehatan Hewan dan Ikan, Dinas Kelautan dan Pertanian Provinsi DKI Jakarta untuk dianalisis. Sampel yang diperoleh adalah sampel darah. Pengujian sampel darah menggunakan metode kajian ini Enzyme Linkked Sorben Assays (ELISA) mengacu pada kit Elisa Rabies Pusat Veteriner Farma.

\section{HASIL DAN PEMBAHASAN}

Surveilans rabies pada tahun 2013 - 2015 telah dilaksanakan yang berasal dari HPR (Hewan Penular Rabies) yaitu anjing, kucing dan kera di lima wilayah DKI Jakarta dan Kabupaten Kepulauan Seribu hasilnya sebagai berikut :

Tabel 1: Protektifitas rabies pada HPR di DKI-Jakarta 2013 - 2015

\begin{tabular}{ccc}
\hline No & Tahun & Protektifitas \\
\hline 1 & 2013 & $31,1 \%$ \\
2 & 2014 & $36,0 \%$ \\
3 & 2015 & $64,0 \%$ \\
\hline
\end{tabular}

Pada tabel 1 terlihat data surveilan tahun 2015 ini memperlihatkan tren kenaikan tingkat protektifitas atau kekebalan kelompok terhadap penyakit rabies yang dimiliki oleh DKI Jakarta. Meskipun secara rata-rata masih $64 \%$ yaitu sedikit lebih rendah dari ketentuan OIE $(70 \%)$, tetapi ini sudah meningkat jauh dibandingkan perolehan rata-rata kekebalan kelompok hasil surveilan tahun sebelumnya (2014) yang hanya $36 \%$ dan 31,1\% pada tahun 2015 .

\begin{tabular}{|c|c|c|c|c|}
\hline No & Wilayah & 2013 & 2014 & 2015 \\
\hline 1 & $\begin{array}{l}\text { Jakarta } \\
\text { Selatan }\end{array}$ & $40,7 \%$ & $40,32 \%$ & $58 \%$ \\
\hline 2 & $\begin{array}{c}\text { Jakarta } \\
\text { Timur }\end{array}$ & $35,4 \%$ & $32,18 \%$ & $75 \%$ \\
\hline 3 & $\begin{array}{c}\text { Jakarta } \\
\text { Barat }\end{array}$ & $29 \%$ & $27,31 \%$ & $67 \%$ \\
\hline 4 & $\begin{array}{c}\text { Jakarta } \\
\text { Pusat }\end{array}$ & $13,2 \%$ & $59,80 \%$ & $64 \%$ \\
\hline 5 & $\begin{array}{c}\text { Jakarta } \\
\text { Utara }\end{array}$ & $34,1 \%$ & $50,45 \%$ & $79 \%$ \\
\hline \multirow[t]{2}{*}{6} & Kep. Seribu & $10,3 \%$ & $3,05 \%$ & $2 \%$ \\
\hline & Rata-rata & $31,1 \%$ & $36 \%$ & $64 \%$ \\
\hline
\end{tabular}

\section{Tabel 2. Protektivitas rabies pada HPR di DKI-Jakarta 2013 - 2015}

Data diatas terlihat proporsi titer protektifitas pada tahun 2015 wilayah Jakarta Utara dan Jakarta Timur sudah memiliki proporsi titer protektif yang cukup tinggi yaitu $79 \%$ dan 75 $\%$. Wilayah Jakarta Barat memiliki proporsi titer $67 \%$ hampir mencapai ambang batas aman. Sedangkan untuk DKI Jakarta pada tahun 2015 telah memperoleh kekebalan kelompok (herd immunity) hewan penular rabies di DKI Jakarta adalah $64 \%$ di bawah ambang batas aman yaitu minimal $70 \%$.

Tabel 3. Hasil pemeriksaan titer rabies

\begin{tabular}{|c|c|c|c|c|}
\hline Kecamatan & Kelurahan & 2013 & 2014 & 2015 \\
\hline Taman Sari & $\begin{array}{l}\text { Glodok } \\
\text { Taman Sari }\end{array}$ & $\begin{array}{l}55,6 \% \\
40 \%\end{array}$ & $38,5 \%$ & $54 \%$ \\
\hline Tambora & Angke & $11,8 \%$ & $14,3 \%$ & $79 \%$ \\
\hline Palmerah & $\begin{array}{l}\text { Kemanggisan } \\
\text { Palmerah }\end{array}$ & $\begin{array}{l}12 \% \\
0 \%\end{array}$ & $35,7 \%$ & $88 \%$ \\
\hline $\begin{array}{l}\text { Grogol } \\
\text { Petamburan }\end{array}$ & $\begin{array}{l}\text { Jelambar } \\
\text { Wijaya } \\
\text { Kusuma }\end{array}$ & $\begin{array}{l}50 \% \\
75 \%\end{array}$ & $50 \%$ & $50 \%$ \\
\hline $\begin{array}{l}\text { Kebon } \\
\text { Jeruk }\end{array}$ & $\begin{array}{l}\text { Kedoya } \\
\text { Selatan } \\
\text { Kedoya Utara }\end{array}$ & $\begin{array}{l}0 \% \\
0 \%\end{array}$ & $44,8 \%$ & $75 \%$ \\
\hline Kembangan & $\begin{array}{l}\text { Kemangan } \\
\text { Utara } \\
\text { Meruya Utara } \\
\text { Srengseng }\end{array}$ & $\begin{array}{l}50 \% \\
37,5 \% \\
75 \%\end{array}$ & $12,5 \%$ & $74 \%$ \\
\hline $\begin{array}{l}\text { Cengkareng } \\
\text { Kalideres }\end{array}$ & Semanan & $12,5 \%$ & $\begin{array}{l}15 \% \\
7,7 \% \\
\end{array}$ & $\begin{array}{l}21 \% \\
57 \% \\
\end{array}$ \\
\hline Rata-rata & & $29 \%$ & $\begin{array}{l}27,31 \\
\%\end{array}$ & $67 \%$ \\
\hline
\end{tabular}
protektif pada HPR di Jakarta Barat 2013 2015 
Data proporsi titer protektif rabies wilayah Jakarta Barat selama tahun 2013 sampai 2015 berdasarkan distribusi per kecamatan terlihat distribusi yang tidak merata baik berdasarkan tahun maupun antar kecamatan. Proporsi titer protektif tiap kecamatan di wilayah Jakarta Barat banyak yang lebih rendah dari target proporsi protektif yang diharapkan yakni $70 \%$. Hampir semua kecamatan di wilayah Jakarta Barat mengalami peningkatan proporsi titer protektif pada tahun 2015 dibandingkan tahun 2014. Pada tahun 2015 ada 4 kecamatan yang mencapai target proporsi titer protektif yaitu Tambora, Palmerah, Kebon Jeruk dan Kembangan. Secara umum target titer protektif di wilayah Jakarta Barat meningkat .

\section{Tabel 4. Titer rabies protektif pada HPR di Jakarta Timur 2013 - 2015}

\begin{tabular}{|c|c|c|c|c|}
\hline Kecamatan & Kelurahan & 2013 & 2014 & 2015 \\
\hline Matraman & $\begin{array}{l}\text { Utan Kayu } \\
\text { Selatan } \\
\text { Utan Kayu } \\
\text { Utara } \\
\text { Palmeriam }\end{array}$ & $\begin{array}{l}100 \\
22,2 \\
50\end{array}$ & $16,7 \%$ & $40 \%$ \\
\hline Pulogadung & Rawamangun & 29,6 & $50 \%$ & $71 \%$ \\
\hline Jatinegara & $\begin{array}{l}\text { Cipinang } \\
\text { Besar Utara } \\
\text { Cipinang } \\
\text { Muara }\end{array}$ & $\begin{array}{l}0 \\
30\end{array}$ & $58,8 \%$ & $94 \%$ \\
\hline Duren Sawit & Duren Sawit & 16,7 & $17,4 \%$ & $67 \%$ \\
\hline Kramat Jati & $\begin{array}{l}\text { Batu Ampar } \\
\text { Cililitan }\end{array}$ & $\begin{array}{l}83,3 \\
10\end{array}$ & $6,7 \%$ & $35 \%$ \\
\hline Makasar & $\begin{array}{l}\text { Makasar } \\
\text { Kebon Pala }\end{array}$ & $\begin{array}{l}44,4 \\
72,7\end{array}$ & $42,9 \%$ & $79 \%$ \\
\hline Pasar Rebo & $\begin{array}{l}\text { Pekayon } \\
\text { Gedong } \\
\text { Cinatung }\end{array}$ & $\begin{array}{l}66,7 \\
100 \\
0\end{array}$ & $8,3 \%$ & $82 \%$ \\
\hline Ciracas & $\begin{array}{l}\text { Kelapa Dua } \\
\text { Wetan } \\
\text { Ciracas } \\
\text { Rambutan }\end{array}$ & $\begin{array}{l}25 \\
0 \\
38,5\end{array}$ & $28,6 \%$ & $100 \%$ \\
\hline Cipayung & Bambu Apus & 40 & $36,8 \%$ & $100 \%$ \\
\hline Cakung & $\begin{array}{l}\text { Penggilingan } \\
\text { Pulau Gedang }\end{array}$ & $\begin{array}{l}0 \\
7,7\end{array}$ & $55,6 \%$ & $100 \%$ \\
\hline Rata-rata & & $\begin{array}{l}35,4 \\
\%\end{array}$ & $\begin{array}{l}32,18 \\
\%\end{array}$ & $75 \%$ \\
\hline
\end{tabular}

Data diatas menunjukkan bahwa secara umum terlihat peningkatan proporsi titer antibody protektif perkecamatan wilayah Jakarta Timur dari hasil surveilans 2013 sampai 2015. Kecamatan Ciracas dan Cakung terlihat hasil proporsi titer antibodi yang rendah pada tahun 2013 yang masih dibawah standar, tahun 2014 meningkat sedikit dan pada tahun 2015 proporsi titer protektif menjadi 100\%. Kecamatan Matraman, Kramat Jati, Makasar dan Pasar Rebo pada tahun 2013 memiliki proporsi titer protektif lebih tinggi dibandingkan pada tahun 2014, selanjutnya meningkat kembali pada tahun 2015. Sedangkan Kecamatan Pulo Gadung, Jatinegara dan Cakung pada tahun 2013 proporsi titer protektifnya hanya kecil, meningkat pada tahun 2014 namun masih dibawah standard dan pada tahun 2015 proporsi titer protektifnya meningkat melebihi standart (lebih dari 70\%). Hasil surveilans tahun 2015 yang menggambarkan 7 kecamatan telah memiliki titer yang baik ini sangat menggembirakan sehingga dengan cakupan titer yang lebih dari target $70 \%$ akan sangat baik untuk membantu mencegah penyakit rabies reemerging/ muncul kembali di wilayah DKI.

\section{Tabel 5. : Hasil Pemeriksaan Titer Rabies pada HPR di Jakarta Pusat 2013 - 2015}

\begin{tabular}{|c|c|c|c|c|}
\hline Kecamatan & Kelurahan & 2013 & 2014 & 2015 \\
\hline Gambir & Petojo Utara & $0 \%$ & $75 \%$ & $71 \%$ \\
\hline $\begin{array}{l}\text { Tanah } \\
\text { Abang }\end{array}$ & Kebon Melati & $10 \%$ & $28,6 \%$ & $77 \%$ \\
\hline \multirow[t]{2}{*}{ Menteng } & Pegangsaan & $\begin{array}{l}18,2 \% \\
\%\end{array}$ & \multirow[t]{2}{*}{$55,6 \%$} & \multirow[t]{2}{*}{$' 85 \%$} \\
\hline & Cikini & $0 \%$ & & \\
\hline Senen & $\begin{array}{l}\text { Kwitang } \\
\text { Bungur }\end{array}$ & $\begin{array}{l}8,3 \% \\
0 \%\end{array}$ & $40 \%$ & $54 \%$ \\
\hline $\begin{array}{l}\text { Cempaka } \\
\text { Putih }\end{array}$ & $\begin{array}{l}\text { Cempaka } \\
\text { Putih Barat }\end{array}$ & $33,3 \%$ & $100 \%$ & $67 \%$ \\
\hline Johar Baru & Johar Baru & $33,3 \%$ & $66,7 \%$ & $52 \%$ \\
\hline Kemayoran & $\begin{array}{l}\text { Cempaka } \\
\text { Baru }\end{array}$ & $25 \%$ & $62,5 \%$ & $65 \%$ \\
\hline \multirow{2}{*}{$\begin{array}{l}\text { Sawah } \\
\text { Besar }\end{array}$} & Pasar Baru & $0 \%$ & \multirow[b]{2}{*}{$50 \%$} & \multirow[b]{2}{*}{$46 \%$} \\
\hline & $\begin{array}{l}\text { Gunung } \\
\text { Sahari Utara }\end{array}$ & $0 \%$ & & \\
\hline Total & & $13,2 \%$ & $59,8 \%$ & $64 \%$ \\
\hline
\end{tabular}

Data diatas memperlihatkan proporsi titer protektif tiap kecamatan di Wilayah Jakarta Pusat bervariasi dan cukup banyak yang lebih rendah dari target cakupan vaksinasi yang diharapkan yakni 70\%. Hanya Kecamatan Gambir yang 2 tahun berturut-turut hasil surveilans di atas standar, walaupun terjadi penurunan di tahun 2015 dibandingkan tahun 2014. Kecamatan lainnya yang terjadi penurunan di tahun 2015 adalah Kecamatan Johar Baru, Sawah Besar dan Cempaka Putih. Kecamatan Tanah Abang dan Menteng menunjukkan hasil peningkatan yang nyata pada tahun 2015 dibandingkan dengan 2013 dan 2014 yang lebih rendah dari target meningkat sampai diatas target protektif yang diharapkan yakni $70 \%$. 
Tabel 6. : Hasil Pemeriksaan Titer Rabies pada HPR di Jakarta Utara 2013 - 2015

\begin{tabular}{|c|c|c|c|c|}
\hline Kecamatan & Kelurahan & 2013 & 2014 & 2015 \\
\hline \multirow[b]{2}{*}{ Cilincing } & Cilincing & $\begin{array}{l}27,3 \\
\%\end{array}$ & \multirow[b]{2}{*}{$32,7 \%$} & \multirow[b]{2}{*}{$60 \%$} \\
\hline & $\begin{array}{l}\text { Semper } \\
\text { Timur }\end{array}$ & $25 \%$ & & \\
\hline Koja & $\begin{array}{l}\text { Rorotan } \\
\text { Tugu Utara } \\
\text { Lagoa }\end{array}$ & $\begin{array}{l}100 \% \\
50 \%\end{array}$ & $87,0 \%$ & $60 \%$ \\
\hline \multirow{2}{*}{$\begin{array}{l}\text { Kelapa } \\
\text { Gading }\end{array}$} & $\begin{array}{l}\text { Klp Gading } \\
\text { Barat }\end{array}$ & $\begin{array}{l}18,2 \\
\%\end{array}$ & \multirow{2}{*}{$40 \%$} & \multirow{2}{*}{$91 \%$} \\
\hline & Pegangsaan & $\begin{array}{l}22,2 \\
\%\end{array}$ & & \\
\hline $\begin{array}{l}\text { Tanjung } \\
\text { Priok }\end{array}$ & $\begin{array}{l}\text { Kebon } \\
\text { Bawang } \\
\text { Warakas }\end{array}$ & $\begin{array}{l}57,1 \% \\
66,7 \%\end{array}$ & $51,3 \%$ & $85 \%$ \\
\hline \multirow{2}{*}{$\begin{array}{l}\text { Pademang } \\
\text { an }\end{array}$} & Pad. timur & $50 \%$ & \multirow{2}{*}{$39,1 \%$} & \multirow{2}{*}{$100 \%$} \\
\hline & Pad. Barat & $60 \%$ & & \\
\hline $\begin{array}{l}\text { Penjaringa } \\
\mathrm{n}\end{array}$ & Pejagalan & $10 \%$ & $52,6 \%$ & $79 \%$ \\
\hline Total & & $34,1 \%$ & $\begin{array}{l}50,45 \\
\%\end{array}$ & $79 \%$ \\
\hline
\end{tabular}

Data di atas terlihat bahwa proporsi titer protektif masing-masing kecamatan wilayah di Jakarta Utara hasil surveilans 2013 sampai 2015 cukup baik kecuali Kecamatan Cilincing dan Koja (2015), tetapi pada tahun 2014 hanya kecamatan Koja yang mempunyai proporsional titer protektif yang melebihi standar. Sedangkan pada tahun 2013 seluruh kecamatan di Jakarta Utara proporsional titer protektif dibawah standar.
Tabel 7. : Hasil pemeriksaan titer rabies pada HPR di Jakarta Selatan 2013 - 2015

\begin{tabular}{|c|c|c|c|c|}
\hline Kecamatan & Kelurahan & 2013 & 2014 & 2015 \\
\hline $\begin{array}{c}\text { Kebayoran } \\
\text { Baru }\end{array}$ & $\begin{array}{l}\text { Gandaria } \\
\text { Utara }\end{array}$ & $61,5 \%$ & $77,8 \%$ & $82 \%$ \\
\hline $\begin{array}{c}\text { Kebayoran } \\
\text { Lama }\end{array}$ & $\begin{array}{l}\text { Melawai } \\
\text { Keb. Lama } \\
\text { Selatan }\end{array}$ & $\begin{array}{l}62,5 \% \\
57,5 \%\end{array}$ & $35 \%$ & $24 \%$ \\
\hline $\begin{array}{l}\text { Pesanggraha } \\
n\end{array}$ & $\begin{array}{l}\text { Petukangan } \\
\text { Selatan } \\
\text { Pesanggrah } \\
\text { an }\end{array}$ & $\begin{array}{l}36,4 \% \\
33,3 \%\end{array}$ & $22,2 \%$ & $86 \%$ \\
\hline Cilandak & $\begin{array}{l}\text { Cilandak } \\
\text { Barat }\end{array}$ & $25 \%$ & $54,8 \%$ & $70 \%$ \\
\hline $\begin{array}{l}\text { Pasar } \\
\text { Minggu }\end{array}$ & $\begin{array}{l}\text { Kebagusan } \\
\text { Pasar } \\
\text { Minggu }\end{array}$ & $\begin{array}{l}100 \% \\
59,3 \%\end{array}$ & $62,1 \%$ & $67 \%$ \\
\hline Jagaraksa & $\begin{array}{l}\text { Cipendak } \\
\text { Srengseh } \\
\text { Sawah } \\
\text { Jagaraksa }\end{array}$ & $\begin{array}{l}0 \% \\
26,3 \% \\
33,3 \%\end{array}$ & $58,1 \%$ & $57 \%$ \\
\hline $\begin{array}{l}\text { Mampang } \\
\text { Prapatan }\end{array}$ & $\begin{array}{l}\text { Pela } \\
\text { Mampang }\end{array}$ & $28 \%$ & $40,7 \%$ & $58 \%$ \\
\hline Pancoran & $\begin{array}{l}\text { Kalibata } \\
\text { Pengadega } \\
n\end{array}$ & $\begin{array}{l}11,1 \% \\
20 \%\end{array}$ & $5 \%$ & $33 \%$ \\
\hline Tebet & $\begin{array}{l}\text { Tebet Barat } \\
\text { Bukit Duri } \\
\text { Manggarai } \\
\text { Menteng } \\
\text { Dalam }\end{array}$ & $\begin{array}{l}81,8 \% \\
57,1 \% \\
22,7 \% \\
50 \%\end{array}$ & $30,8 \%$ & $60 \%$ \\
\hline Setiabudi & Setiabudi & $30,8 \%$ & $16,7 \%$ & $62 \%$ \\
\hline Total & & $40,7 \%$ & $\begin{array}{c}40,32 \\
\% \\
\end{array}$ & $58 \%$ \\
\hline
\end{tabular}

Data proporsi titer protektif rabies wilayah Jakarta Selatan selama 2013 sampai 2015 berdasarkan distribusi perkecamatan maka terlihat distribusi yang tidak merata baik berdasarkan tahun maupun antar kecamatan. Kecamatan Kebayoran Lama perlu mendapat perhatian karena pada tahun 2013 memiliki titer $57,5 \%$ terus mengalami penurunan selama dua tahun kedepan yaitu $33 \%$ pada tahun 2014 dan $24 \%$ pada tahun 2015. Kecamatan Kebayoran Baru dan Cilandak menunjukkan hasil peningkatan yang nyata pada tahun 2015 mencapai ketentuan proporsi titer protektip dibandingkan dengan 2013 dan 2014 
Tabel 8. : Hasil pemeriksaan titer rabies pada HPR di Kepulauan Seribu 2013 - 2015

\begin{tabular}{|c|c|c|c|c|}
\hline Kecamatan & Kelurahan & 2013 & 2014 & 2015 \\
\hline $\begin{array}{l}\text { P. Seribu } \\
\text { Utara }\end{array}$ & $\begin{array}{l}\text { P. } \\
\text { Panggang } \\
\text { P. } \\
\text { Harapan } \\
\text { P. Kelapa } \\
\text { P. } \\
\text { Pramuka } \\
\text { P. Kelapa } \\
\text { Dua }\end{array}$ & $\begin{array}{l}0 \% \\
0 \% \\
0 \% \\
5 \% \\
25 \%\end{array}$ & $6,1 \%$ & $0 \%$ \\
\hline $\begin{array}{l}\text { P. Seribu } \\
\text { Selatan }\end{array}$ & $\begin{array}{l}\text { P. Tidung } \\
\text { P. } \\
\text { Pari/Lanc } \\
\text { ang } \\
\text { P.Untung } \\
\text { Jawa }\end{array}$ & $\begin{array}{l}8,3 \% \\
37,5 \% \\
0 \%\end{array}$ & $0 \%$ & $1 \%$ \\
\hline Total & & $10,3 \%$ & $3,05 \%$ & $2 \%$ \\
\hline
\end{tabular}

Data di atas memperlihatkan proporsi titer protektif rabies pada masing-masing kecamatan di Kepulauan Seribu. Kecamatan tertinggi persentase protektipnya pada tahun 2014 adalah Kecamatan Seribu Utara (6,1 \%). Kabupaten Kepulauan Seribu perlu mendapat perhatian serius karena prosentase protektifitas dari tahun 2013 sampai 2015 terus menurun

Dari data surveilan tahun 2015 memperlihatkan tren kenaikan tingkat protektivitas atau kekebalan kelompok terhadap penyakit rabies yang dimiliki oleh DKI Jakarta. Meskipun secara rata rata masih $64 \%$ yaitu sedikit lebih rendah dari harapan ketentuan OIE (70\%), tetapi ini sudah meningkat jauh dibandingkan perolehan rata rata kekebalan kelompok hasil surveilan tahun-tahun sebelumnya yang hanya $36 \%$ (2014) dan 31,1\% (2013). Bahkan kalau dilihat per wilayah maka Jakarta Pusat dan Jakarta Timur sudah memiliki proporsi titer protektif yang cukup tinggi yaitu $79 \%$ dan $75 \%$. Wilayah Jakarta Barat dan Jakarta Pusat hampir mendekati syarat kecukupan yakni $67 \%$ dan $64 \%$. Jakarta Selatan yang saat ini paling rendah untuk wilayah daratan juga memiliki proporsi titer protektif yang lumayan yakni $58 \%$. Kepulauan Seribu masih perlu perhatian khusus karena titer protektifnya paling rendah, meskipun wilayah ini memiliki barier alam yang baik tetapi jika ada introduksi virus rabies yang mungkin dibawa oleh fihak yang kurang bertanggung jawab akibatnya akan cepat meyebar ke HPR yang lain karena kurang adanya perlindungan dari kekebalan kelompok.

Dari deskripsi hasil yang dapat diamati terlihat bahwa tingkat protektivitas terhadap rabies di
DKI Jakarta pada tahun 2015 adalah hanya $64 \%$ dan meningkat cukup tinggi dari tahuntahun sebelumnya yang hanya $36 \%$ (2014) dan $31,1 \%$ (2013) mendekati target yang diharapkan yaitu 70\% kekebalan kelompok yang dibutuhkan untuk mencegah dan memutus siklus penularan virus rabies bila ada. Bahkan beberapa wilayah sudah memiliki titer protektif diatas $70 \%$ yaitu Jakarta Utara $79 \%$ dan Jakarta Timur 75\%, Jakarta Barat dan Jakarta Pusat proporsi titer protektifnya juga cukup lumayan mendekati $70 \%$. Hanya di Kepulauan Seribu masih ditemukan kondisi yang sangat memperihatinkan karena titer protektifnya sangat rendah, meskipun wilayahnya memiliki barier alam yang baik berupa lautan untuk mencegah penularan rabies dari hewan ke hewan langsung, tetapi aktivitas manusia yang tidak memahami membawa HPR yang terinfeksi maka akibatnya akan sangat merugikan.

Dua hal penting dalam pencegahan rabies adalah dengan menjaga kekebalan kelompok (herd immunity) yaitu dengan mempertahankan cakupan titer protektif lebih dari $70 \%$ sesuai dengan anjuran OIE dan juga pengendalian HPR terutama pengawasan terhadap HPR liar dan lalulintas HPR. Berdasarkan data tingkat protektivitas secara umum wilayah Jakarta yang cukup rendah maka dapat dikatakan saat ini jika ada introduksi virus rabies dari wilayah lain maka kekebalan kelompok yang dimiliki Jakarta untuk menahan virus tersebut menginfeksi wilayah ini tidak mencukupi. Tindakan yang paling penting dilakukan saat ini adalah jika dimungkinkan dilakukan segera vaksinasi masal ulang, pengawasan lebih ketat HPR liar, diusahakan tidak ada HPR liar yang berkeliaran di Jakarta karena hewan inilah resiko utama penularan penyakit terjadi. Pengawasan lalulintas menjadi hal yang tidak boleh dilupakan karena titer antibodi yang didapat dari hewan yang tidak diketahui sejarah vaksinasinya adalah kemungkian berasal dari luar wilayah. Adanya titer antibodi pada individu tanpa vaksinasi mengharuskan wilayah Jakarta harus lebih waspada terhadap pengawasan lalulintas dan HPR dari luar wilayah. Mengingat kasus rabies yang muncul di Bali dan juga Flores yang tidak kunjung tuntas pemberantasannya maka mempertahankan wilayah DKI Jakarta tetap bebas rabies menjadi hal yang tidak boleh ditawar lagi. Surveilan yang berkelanjutan terhadap penyakit yang sangat membahayakan baik pada hewan maupun pada manusia selau dilaksanakan. Menghindari kemungkinan munculnya kembali rabies (re-emerging) seperti kasus di Jawa 
Barat dan Banten perlu dukungan dari semua fihak terkait bukan hanya dinas yang membidangi kesehatan hewan teapi juga intansi terkait seperti dinas Kesehatan Dinas Pariwisata dan lain lain.

Hingga tahun 2010 hanya ada 10 provinsi yang bebas yaitu Kepulauan Riau, Bangka Belitung, DKI Jakarta, Jawa Tengah, D.I.Yogyakarta, Jawa Timur, Kalimantan Barat, NTB,Papua Barat dan Papua. Kejadian di Kalimantan Barat bersifat sporadik namun sejak 2005-2009 tidak ditemukan lagi rabies sehingga telah dinyatakan bebas. Target pembebasan terus mengalami penurunan. Pulau Sumatra dan Kalimantan yang ditargetkan bebas tahun 2007 sampai sekarang belum terlaksana. Demikian pula yang terjadi pada Sulawesi, Maluku dan Pulau Flores.

Kasus terakhir penyakit rabies di Propinsi DKI Jakarta terjadi pada awal tahun1995 dan sejak saat itu sampai tahun 2004 Provinsi DKI Jakarta bebas kasus rabies. Pada tanggal 6 Oktober, Provinsi DKI Jakarta dinyatakan bebas rabies berdasarkan Keputusan Menteri Pertanian No : 566/Kpts/PD.640/ID/2004 tentang Pernyataan Provinsi DKI Jakarta, Banten dan Jawa Barat bebas dari Penyakit Anjing Gila (Rabies). Tetapi dengan berjalannya waktu Propinsi Jawa Barat telah terserang Penyakit Rabies kembali, sehingga Provinsi DKI Jakarta dikelilingi oleh daerah endemis rabies. Banyaknya pintu masuk menuju Propinsi DKI Jakarta dan kurangnya petugas sehingga lalu lintas lewat darat sulit diawasi sedangkan karantina membolehkan lalu lintas HPR dari daerah tertular menuju ke daerah lain yang tertular, maka Provinsi DKI Jakarta harus tetap waspada dalam mempertahankan tetap bebas

Dengan semakin meningkatnya kegemaran masyarakat memelihara hewan seperti anjing dan kucing sebagai salah satu hewan kesayangan, maka meningkat pula morbilitas peredaran Hewan Penular Rabies di wilayah Propinsi DKI Jakarta. Dalam rangka menjamin kesehatan hewan rentan rabies dan melindungi masyarakat dari bahaya penyakit Rabies, Pemerintah Propinsi DKI Jakarta telah menerbitkan Peraturan Daerah DKI Jakarta Nomor 11 Tahun 1995 tentang Pengawasan Hewan Rentan Rabies Serta Pencegahan dan Penanggulangan Rabies di DKI Jakarta dan Instruksi Gubernur Provinsi DKI Jakarta Nomor 73 Tahun 2012 tentang Kewaspadaan Penularan Penyakit Rabies.
Kewaspadaan terhadap penyakit Rabies tetap diperlukan untuk mencegah adanya penyakit, mengingat masa inkubasi penyakit Rabies cukup lama dan DKI Jakarta berbatasan dengan daerah tertular, maka kegiatan pengawasan lalulintas Hewan Penular Rabias secara ketat dan pembentukan "Sabuk Kebal" melalui kegiatan Vaksinasi Serentak disepanjang perbatasan harus dilakukan setiap tahun.

Berbagai kegiatan dilakukan untuk pelaksanaan pencegahan dan pengendalian penyakit rabies antar lain : sosialisasi dan edukasi, vaksinasi rabies, penangkapan HPR liar, eliminasi, sterilisasi, observasi terhadap HPR yang menggigit. Pengawasan lalu lintas HPR dan Bakor rabies tingkat provinsi dan wilayah serta surveilans.

Pada tanggal 28 September 2011, propinsi DKI Jakarta mendapatkan penghargaan dari menteri Pertanian Republik Indonesia karena prestasinya mempertahankan wilayah bebas penyakit rabies.

Telah dibuat sistem online dalam penanganan kasus penggigitan oleh HPR pada manusia, dengan tujuan respon cepat dalam penanganan kasus penggigitan terhadap manusia serta HPR yang menggigit terlacak untuk segera di observasi di Rumah Observasi Rabies. Sistem ini merupakan koordinasi antara Dinas Kelautan dan Pertanian dengan Rumah Sakit Rujukan (RSUD Tarakan dan RSPI Sulianti Saroso) serta 5 wilayah kota dan 1 Kabupaten Suku Dinas yang membidangi Peternakan dan Rumah Observasi Rabies Balai Kesehatan Hewan dan Ikan.

Kenyataan Rabies telah menyebar hampir seluruh wilayah di Indonesia. Pada kajian ini metode yang digunakan Enzyme Linkked Sorben Assay (ELISA) mengacu pada kit Elisa Rabies Pusat Veteriner Farma, maka perlu ditetapkan SNI Rabies sebagai acuan standart yang bagi laboratorium-laboratorium di Indonesia. Hal ini penting mengingat kejadian Rabies di Indonesia cukup menghawatirkan terlebih bersifat menular ke manusia.

\section{KESIMPULAN}

Hasil kajian penyakit rabies di DKI Jakarta tahun 2013 sampai 2015 dapat disimpulkan sebagai berikut:

a) Kekebalan kelompok (herd immunity) hewan penular rabies di DKI Jakarta mulai tahun 
2013 sampai 2015 memperlihatkan tren kenaikan tingkat protektifitas atau kekebalan kelompok terhadap penyakit rabies yang dimiliki oleh DKI Jakarta. Meskipun secara rata-rata masih $64 \%$ yaitu sedikit lebih rendah dari ketentuan OIE (70\%), tetapi ini sudah meningkat jauh dibandingkan perolehan rata-rata kekebalan kelompok hasil surveilan tahun sebelumnya (2014) yang hanya $36 \%$ dan $31,1 \%$ pada tahun 2013 kurang dari ketentuan OIE yaitu $70 \%$. Kepulauan seribu masih perlu perhatian khusus karena cakupan vaksinasi dan titer protektifnya paling rendah, meskipun wilayah ini memiliki barier alami yang baik tetapi jika ada introduksi virus rabies yang mungkin dibawa oleh fihak yang kurang bertanggung jawab akibatnya akan cepat meyebar ke HPR yang laian karena kurang adanya perlindungan dari kekebalan kelompok.

b) Pada tahun 2015 wilayah Kotamadya yang memiliki titer protektif yang cukup adalah wilayah Kotamadya Jakarta Utara (79\%) dan Jakarta Timur (75\%), sedangkan wilayah lainnya masih dibawah $70 \%$. Capaian proporsi titer protektif DKI jakarta adalah $64 \%$ Dengan capaian titer ini DKI beresiko kemungkinan rabies re-emerging (muncul kembali) di wilayah DKI Jakarta jika ada introduksi agen virus rabies yang terbawa masuk ke DKI Jakarta. Kajian ini dapat digunakan sebagai bahan masukkan bagi pimpinan untuk pencegahan dan pengedalian rabies di propinsi DKI Jakarta.

c) Sampel darah yang diambil berasal dari anjing, kucing dan kera diuji dengan metode uji Elisa (Enzyme Linked Immunosorbent Assays) mengacu kit Elisa Rabies Pusat Veteriner Farma.

\section{SARAN}

a) Metode yang digunakan pada kajian ini Enzyme Linkked Sorben Assay (ELISA) mengacu pada kit Elisa Rabies Pusat Veteriner Farma, maka perlu ditetapkan SNI Rabies sebagai acuan standart yang bagi laboratorium-laboratorium di Indonesia.

b) Hal-hal yang perlu ditingkatkan untuk lebih mengoptimalkan pencegahan rabies muncul kembali di DKI Jakarta yang sudah dinyatakan bebas adalah dengan segera meningkatkan proporsi titer antibodi protektif rabies dengan segera vaksinasi ulang, menjaga jangan ada HPR liar yang berkeliaran dan pengawasan lalulintas hewan penular rabies ke Jakarta lebih diperketat.

c) Mengingat pentingnya kekebalan kelompok ini maka supaya segera dilakukan tindakan evaluasi menyeluruh tentang pelaksanaan vaksinasi DKI Jakarta termasuk cakupan vaksinasi, manajemen penanganan vaksin rabies termasuk penyimpanan dan penanganan rantai dingin vaksin.

d) Dengan kekebalan kelompok yang rendah pada HPR (Hewan Penular Rabies), maka perlu pengawasan lalulintas Hewan Penular Rabias secara ketat dan pembentukan "Sabuk Kebal" melalui kegiatan Vaksinasi Serentak disepanjang perbatasan harus dilakukan setiap tahun.

\section{DAFTAR PUSTAKA}

Arthur Schoenstadt, MD (2017). Diagnosis of rabies in Animals: Rabies symptoms, Jan 262017 from rabies emedtv.com : Rabies Symtoms.

Chaltron, K.M. Nadin Davis,S., Casey, G.A and Wandeler, A.I (1997). The long incubation period in rabies: delayed proggession of infection in the muscle at the site of expresure. Acta Neurophatologia.

Direktorat Kesehatan Hewan, Direktorat Jenderal Peternakan dan Kesehatan Hewan, Kementerian Pertanian Republik Indonesia (2014). Pedoman Teknis Surveilans Penyakit Hewan Menular.

Jackson, A.C (2000). Rabies Canadian journal of neurological sciences 27 .

Madigan MT, Matinko JM, Dumlap PV, Clark PP (2009). Brock Biology of Microorganisms, Twelfth Edition.

Mrak RE, Young L (1994), Rabies encephalitis in humans : pathology, pathogenesis and pathophysiology, J Neurophathol Exp Neurol.

Nadin-Davis, S.A., Huang W., Armstrong J., Casey G.A.C., Tardo, N Wandeler A.I. (2001). Antigenic and genetic divergenence of rabies viruses from bat species indigenous to Canada. Virus Research 74. 
Rabies-Bulletin-Europa (2011). Diagnosis of rabies in Animals, Jan 27, 2017 from who-rabies-buletin.org: Diagnosis of Rabies in animals

Sacramento D, Badrane H, Bourhy H,Tordo N (1992). Molecular epidemiology of rabies virus in Franc comparison with vaccine strain.

Smith JS (1996). New Aspects of Rabies with Emphasis on Epidemiology, Diagnosis, and Prevention of the Disease in the United States. Di Bali positip rabClin Microbiol Rev 9 (2).

Steele, J. H. and Fernandez, P. J. (1991). History of rabies and global aspects. In: Baer, G. M. [ed.] The natural history of rabies, 2nd ed. pp. 415-425. CRC, Boca Raton Florida. USA.

U.S Department of Health and Human services (2011), Center for Disease Control and Prevention : Rabies Diagnosis in Animal and Human, September 20, 2011 from animalhealthchannel.com.

U.S Department of Health and Human services (2014), Center for Disease Control and Prevention : Rabies Vaccine, September 24, 2014 from cdc.gov: Medical care rabies.

Tsiang, H.Ceccaldi, P.E. and Lyckey, E (1991) Rabies virus infection and transport in human sensory dorsal ganglia neurons. Journal of general virology 72 .

Wirblich C.Tan GS, Papaneri A,Godlewski pj orenstein JM, HArty RN, Schnelle MJ (2008) PPEY motifff within the rabies virus (RV) matrix protein is essensial for efficient virion release and $R V$ pathogenicity.

Wunner, W. H., Larson, J. K., Dietzschold, B. and Smith, C.L. (1988). The molecular biology of rabies viruses. Rev. Infect. Dis. 10, S771-S784. 